\title{
When China Sneezes Does ASEAN Catch a Cold?
}




\title{
WP/16/214
}

\section{IMF Working Paper}

\section{When China Sneezes Does ASEAN Catch a Cold?}

\author{
Sohrab Rafiq
}

IMF Working Papers describe research in progress by the author(s) and are published to elicit comments and to encourage debate. The views expressed in IMF Working Papers are those of the author(s) and do not necessarily represent the views of the IMF, its Executive Board, or IMF management.
I N T E R N A T I O N A L
$M O N E T A R Y$
F U N D 


\title{
IMF Working Paper
}

Asia and Pacific Department

\section{When China Sneezes Does ASEAN Catch a Cold?}

\author{
Prepared by Sohrab Rafiq ${ }^{1}$
}

Authorized for distribution by John Nelmes

November 2016

\begin{abstract}
This Working Paper should not be reported as representing the views of the IMF. The views expressed in this Working Paper are those of the author and do not necessarily represent those of the IMF or IMF policy. Working Papers describe research in progress by the author(s) and are published to elicit comments and to further debate.
\end{abstract}

This paper looks at the effects of a China slowdown on Emerging Market Economies (Indonesia, Malaysia, and Thailand) and Frontier Developing Economies (Cambodia, Lao P.D.R., and Vietnam) in ASEAN. The main finding is that the impact of China growth shocks on ASEAN has risen since the global financial crisis. A one percent decline in China's growth implies a 0.3 percent reduction in growth for ASEAN EMEs and 0.2 for FDEs. An important component of inflation is also shared between ASEAN and China. These magnitudes are double what they were two decades ago due to stronger trade and financial linkages. Finally, a slowdown in China, while having real effects, also has a financial impact via slower credit growth and lower equity prices. This is in line with the existence of both portfolio balance and signaling channels, in which ASEAN market participants absorb news on China economic activity as an indicator over domestic growth prospects.

JEL Classification Numbers: E52, E62, F41

Keywords: China, spillovers, financial, ASEAN, time-varying

Author's E-Mail Address: $\quad$ srafiq@imf.org

\footnotetext{
${ }^{1}$ The author wishes to thanks seminar participants in the Asia and Pacific Department, Changyong Rhee, Markus Rodlauer, John Nelmes, Sonali Jain-Chandra, Ranil Salgado Manohara, Jaewoo Lee, Alex Mourmouras, Elena Loukoianova, Joong Shik Kang, Jaime Guajardo, and Ranee Sirihorachai.
} 
I. Introduction

II. An Open Economy Structural Factor Model of China and ASEAN................................ $\overline{5}$

III. World, China, and ASEAN Macroeconomic Shocks …............................................. $\underline{9}$

A. How has the Size of China Growth Shocks on ASEAN Changed? ............................... $\underline{9}$

B. Explanatory Power of China Growth Shocks on the ASEAN Economic Cycle............11

IV. Innovation Accounting of A China Slowdown on ASEAN ......................................... $\frac{12}{12}$

A. What is the Impact of China's Growth on ASEAN Economic Activity? .....................12

B. Does a Slowdown in China Influence Financial Conditions in ASEAN? ....................13

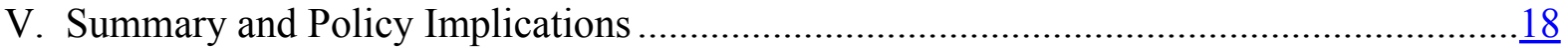

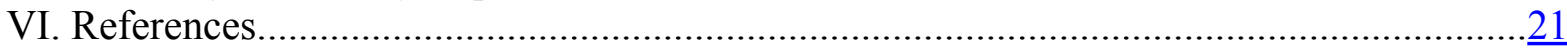

\section{Box}

1. Measuring China Economic Activity in Real-Time ............................................... $\underline{8}$

\section{FIGURES}

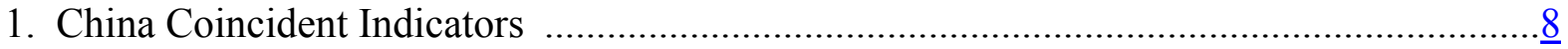

2. China Real-Time Coincident Indicator Index .............................................................. $\frac{8}{8}$

3. Size of China and ASEAN Macroeconomic Shocks, 2005-15 .....................................10

4. Time-Varying Variance Decomposition for ASEAN Economic Activity .......................11

5. Elasticity Value to a Change in China Economic Growth …........................................12

6. Response of ASEAN Inflation Dynamics to a China Growth Slowdown .......................13

7. ASEAN Financial Cycle and Global Risk Aversion ....................................................14

8. Response of Equity and Long-Term Rates in ASEAN to a China Slowdown .................... $\underline{16}$

9. Response of Credit Cycle in ASEAN to a China Slowdown..........................................17

\section{APPENDICES}

A. Data Definitions and Panel Blocks .......................................................................... 19

B. Response of ASEAN Economic Activity to a Slowdown in China Economic Activity.... $\underline{\underline{20}}$ 


\section{INTRODUCTION}

This paper seeks to characterize changes in ASEAN macroeconomic dynamics due to the effect of China developments. The paper then focuses on the evolution of these forces. The last two decades have witnessed rapid trade and financial integration between ASEAN and China. Exports from ASEAN to China have grown from three percent of ASEAN GDP in 2000 to eight percent of GDP in 2015, while financial linkages have also strengthened due to FDI and portfolio flows from China to ASEAN. ${ }^{2}$ To reflect these structural changes this paper proposes a model which conditions spillovers from China on changes in network connectedness with ASEAN, while accounting for tail-risk external shocks from global and China's economic growth to ASEAN economies. In essence, the framework captures the changing comovements among macroeconomic variables by allowing their dependence on common factors to evolve over time.

This paper finds that the importance of China growth shocks for ASEAN has risen since the 2008 Global Financial Crisis (GFC). A slowdown in China of one percent of GDP relative to trend growth reduces economic activity by around 0.3 percent in ASEAN emerging market economies (EMEs) and 0.2 percent in frontier and developing economies (FDEs). These magnitudes are double in size compared to two decades ago. A China growth slowdown also pushes deflationary pressures on the region, implying a component of consumer price inflation in ASEAN is shared with China. The experience of ASEAN EMEs implies that as ASEAN FDEs' trade and financial linkages grow they are increasingly likely to be buffeted by shocks from China, strengthening calls for preemptively upgrading macroeconomic and macroprudential frameworks.

An economic downturn in China also leads to a decline in asset prices and tightened monetary conditions across the region. This effect has strengthened over the last 15 years, suggesting the emergence of an Asian financial cycle, and implies that ASEAN may unintentionally import financial conditions from China. The results are consistent with the growing importance of China as a net transmitter of financial shocks. As China reforms its exchange rate regime, the findings raise the issue of foreign exchange rate management in ASEAN and the potential benefits of greater flexibility.

This paper is organized as follows. Section 2 lays out an empirical open economy macro model, including the structural identification scheme and data definitions. Sections 3 and 4 discuss the results from the model with Section 5 concluding.

\footnotetext{
${ }^{2}$ See Chapter 2 'Rising Tide: Trade and Financial Spillovers from China' in Asia and Pacific Regional Economic Outlook (April 2016).
} 


\section{An Open Economy Structural Factor Model Of China AND ASEAN}

This section sets out a structural model containing China and a group of Frontier Developing Economies (Cambodia, Lao PDR and Vietnam) and Emerging Market Economies (Indonesia, Malaysia, Thailand and Philippines) in ASEAN. Empirically, the issue is addressed by examining a multi-equation structural factor model. The starting point is the following restricted two-block VAR model:

$$
\left(\begin{array}{c}
X_{t}^{W} \\
X_{t}^{A}
\end{array}\right)=\left(\begin{array}{cc}
B_{11}(L) & 0 \\
B_{21}(L) & B_{22}(L)
\end{array}\right)\left(\begin{array}{l}
X_{t-1}^{c} \\
X_{t-1}^{A}
\end{array}\right)+u_{t}
$$

where $X_{t}^{W}=\left[y_{t}^{g}, y_{t}^{c}\right]$ includes a measure of global economic activity from Kilian (2009) and a variable to capture broad economic activity shifts in China. ${ }^{3}$ A measure of real global economic activity is included in order to isolate China-specific growth shocks to ASEAN economies. The second block $X_{t}^{A}$ includes a measure of economic activity, inflation, credit growth and equity prices, and interest rates for each ASEAN country. The structure of $B(L)$ reflects the small open economy assumption, and implies that ASEAN countries are unable to influence China directly.

To attain structural factor inference, the panel of macroeconomic time-series $X_{t}^{A}$ is broken down into subsets (or blocks), which loads specific variables on factors to give a structural interpretation:

$$
\left(\begin{array}{c}
X_{t}^{W} \\
X_{t}^{y} \\
X_{t}^{\pi} \\
X_{t}^{c} \\
X_{t}^{e}
\end{array}\right)=\left(\begin{array}{ccccc}
1 & \cdots & \cdots & \cdots & 0 \\
0 & \Gamma_{t}^{y} & \cdots & \cdots & \vdots \\
\vdots & \cdots & \Gamma_{t}^{p} & \cdots & \vdots \\
\vdots & \cdots & \cdots & \Gamma_{t}^{c} & \vdots \\
0 & \cdots & \cdots & \cdots & \Gamma_{t}^{e}
\end{array}\right)\left(\begin{array}{c}
X_{t-1}^{c} \\
F_{t}^{y} \\
F_{t}^{\pi} \\
F_{t}^{c} \\
F_{t}^{e}
\end{array}\right)+v_{t}
$$

Following Boivin and Giannoni (2010) international factor model, the foreign (China) block $\left(X_{t}^{c}\right)$ is included in the domestic (ASEAN) factor block. The measurement equation (2) relates the observed variables in the blocks $X_{t}^{i}$ to $\Gamma_{t}^{i}$ the state vector. The $X_{t}^{y}$ is a $7 \times 1$ block of ASEAN economic activity variables; $X_{t}^{\pi}$ is a $7 \times 1$ block of ASEAN inflation variables; $X_{t}^{c}$ is a $7 \times 1$ block of ASEAN credit growth variables; $X_{t}^{e}$ is an $10 \times 1$ block containing time-series on ASEAN equities and bond yields.

The four unobserved factors, rotated to be orthogonal to one another $\left(F_{t}^{y}, F_{t}^{\pi}, F_{t}^{c}, F_{t}^{e}\right)$, are interpreted as a real activity factor, an inflation dynamic factor, a credit cycle factor and an

\footnotetext{
${ }^{3}$ As a high frequency measure, Ravazzolo and Vespignani (2015) have shown the Kilian (2009) index of global real economic activity accurately tracks global GDP growth rates.
} 
asset price factor. ${ }^{4}$ The unobserved factors $\left(F_{t}^{i}\right)$ and factor loadings $\left(\Gamma_{t}^{i}\right)$ are estimated as in Del Negro and Otrok (2008). The factor loadings in the measurement equation (2) are assumed to evolve according to the law of motion equation

$$
\Gamma_{t}^{i}=\Gamma_{t-1}^{i}+\xi_{t}
$$

This assumed structure is an efficient way of introducing non-linear (time-varying) dynamics into the model. Time-varying loadings can be thought of as an approach to network connectedness measurement, in this case between ASEAN EMEs/FDEs and China.

In addition to including a financial block $\left(X_{t}^{e}\right)$ containing financial time-series, thereby specifying a forward-looking structural component in the framework, and by letting the variables change as a result of increasing goods and financial market integration, the model is more robust to the Lucas critique. Moreover, by incorporating the amplification channels through credit and financial markets, the model here is consistent with a general-equilibrium approach to external spillovers. Finally, incorporating additional information sets in a structural model helps limit omitted variable bias and improve accuracy by reducing the probability of the observed variables failing to perfectly reveal the state variables of the model (the non-invertability problem). This should ensure that current and past values of China's growth in the model contain enough information to recover the 'true' structural shock.

The dynamics of the measurement equation (1) is postulated to follow the law of motion equation

$$
z_{t}=\sum_{i=1}^{L} \phi_{l, t} z_{t}+\psi_{t}
$$

where $z_{t}=\left[X_{t}^{W}, F_{t}^{y}, F_{t}^{\pi}, F_{t}^{c}, F_{t}^{e}\right]$.

Following Primiceri (2005), the covariance matrix of the innovations $\psi_{t}$ is factored as

$$
\begin{gathered}
\operatorname{VAR}\left(\psi_{t}\right)=A_{t}^{-1} H_{t} A_{t} \\
H_{t}=\left[\begin{array}{ccc}
h_{1, t} & \cdots & 0 \\
\vdots & \ddots & \vdots \\
0 & \cdots & h_{n, t}
\end{array}\right] \quad A_{t}=\left[\begin{array}{ccc}
a_{11, t} & \cdots & 0 \\
a_{21, t} & \ddots & \vdots \\
a_{n n, t} & \cdots & a_{n n-1, t}
\end{array}\right]
\end{gathered}
$$

\footnotetext{
${ }^{4}$ Other papers have applied restrictions in a factor model to allow for a clearer interpretation of the factors. Rey (2015) uses financial market data loaded on a single factor to identify a global financial cycle in a VAR model. Helbling, Kose, Otrok, and Huidrom (2010) use restrictions on factors to identify global inflation and credit cycles. Justiniano (2004) adopts Bayesian methods to derive factors that can be interpreted as country-specific shocks. Clark and Shin (2000) find that a common factor accounts substantial variations in industrial production of European economies, and Lumsdaine and Prasad (2003), examining industrial output in 17 OECD countries and a common component, find evidence of a world business cycle.
} 
The contemporaneous coefficients evolve according to the random walk

$$
a_{i j, t}=a_{i j, t-1}+\gamma_{i, t}
$$

The stochastic volatility follows the specified law of motion equation

$$
h_{i, t}=h_{i, t-1}+\zeta_{i, t}
$$

This assumption allows the size of China growth shocks to ASEAN to change over time to better account for tail risk disturbances. The empirical literature has documented significant variation in the evolution of global and Asian economic cycle volatility over the last few decades.

Finally, the model relies upon the use of monthly data running from 2003:1 till 2015:6 for estimation purposes. ${ }^{5}$ All data are ensured to lie within the unit circle, and enter the system contemporaneously. Data definitions are provided in Appendix A. The model is estimated using Bayesian methods based on Markov Chain Monte Carlo (MCMC) simulations, as in Rafiq (2013, 2014, 2015a).

\footnotetext{
${ }^{5}$ Apart from increasing degrees of freedom, the use of monthly data has a number of advantages: (i) high frequency data will better capture smooth transition shifts between ASEAN and China macroeconomic data; (ii) it will prevent the common component between ASEAN and China being over estimated; (iii) the data, and therefore results, will suffer from less aggregation bias.
} 


\section{Box 1: Measuring China Economic Activity in Real-Time}

A high frequency (coincident) index of China economic activity is constructed using a mixed data sampling model to track economic activity in real-time. The coincident indicator is constructed on demeaned, seasonally adjusted year-on-year growth rates of four variables: industrial production, residential investment and retail sales (all monthly), and real GDP (quarterly). These series are shown in Figure 1. The mixed frequency data single-index model is expressed as:

$$
\Delta y_{t}=\gamma C_{t}+u_{t}
$$

where $\Delta y_{t}$, and $\gamma$ are all $4 \times 1$ vectors as is $u_{t}$. The index is a common growth rate $\left(C_{t}\right)$ across the four series, which represent the current underlying state of the economy. The common component is allowed to enter each series with a different weight $(\gamma)$. The index is a common growth rate $\left(C_{t}\right)$ across the four series, which represent the current underlying state of the economy. The dynamic factor model implies the comovements of the multiple time coincident series arise from a single source $\left(C_{t}\right)$, which is assumed to follow a stationary $\mathrm{AR}(3)$ process. The errors terms $\left(u_{t}\right)$ are assumed to follow an $A R(2)$

Figure 1: China Coincident Indicators
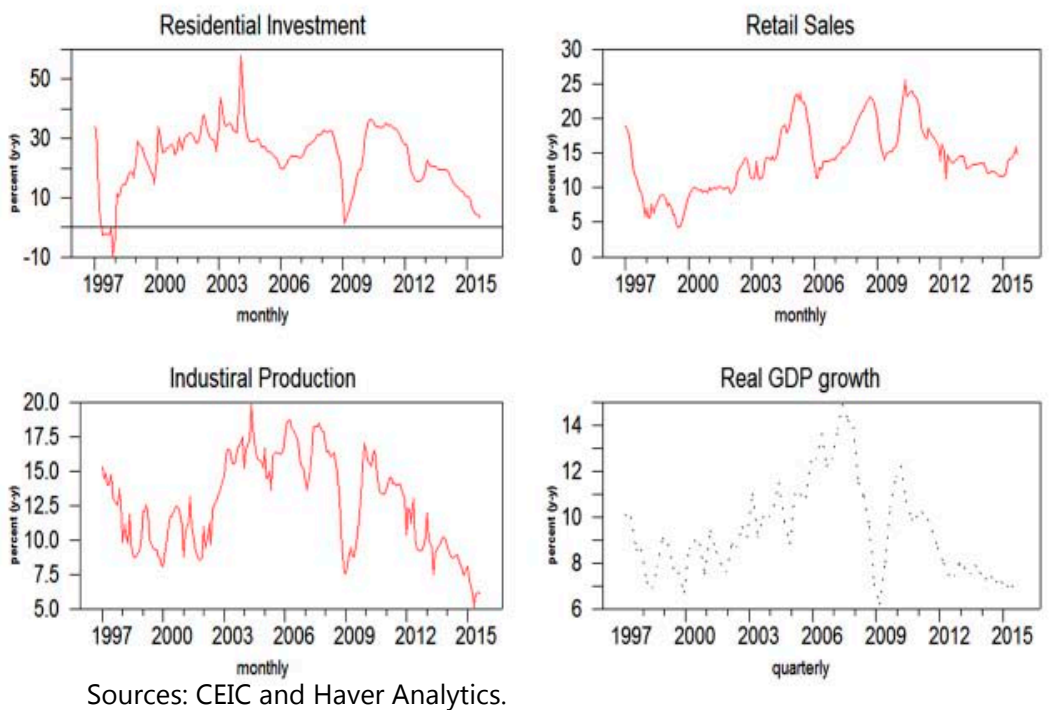
and are independent of $C_{t}$. The real-time coincident index is estimated using a modified version of Stock and Watson's (1989) statespace model and Kalman filter.

Figure 2 illustrates the demeaned coincident indicator. A positive value of the index would be associated with above average growth. The index shows that, while more volatile due to being composed of high frequency series the China monthly, economic activity indicator has, in general, tracked changes in the Figure 2: China Real-Time Coincident Indicator

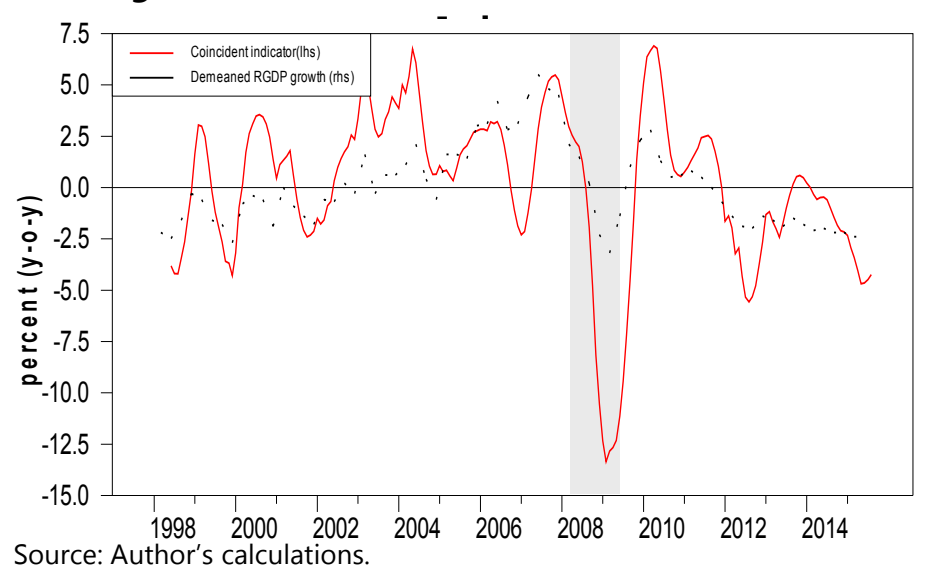
direction of final vintage real GDP growth since 1998. 


\section{World, ChINA, AND ASEAN MACROECONOMIC SHOCKS}

This section illustrates changes in the size of world and China growth shocks and their frequency, and their relative explanatory power for macroeconomic fluctuations across ASEAN.

\section{A. How has the Size of China Growth Shocks on ASEAN Changed?}

Figure 3 illustrates the stochastic volatility estimates $\left(H_{t}\right)$, which proxy for changes in the size of economic shocks in China and ASEAN macroeconomic cycles. More precisely, the volatilities are calculated using

$$
\xi_{t}=\left(\Xi_{t}^{\prime} H_{t} H_{t}^{\prime} \Xi_{t}\right)^{.5}
$$

where $\Xi_{t}$ is a $n \times 1$ vector with a one in the $j^{t h}$ element and zero elsewhere. The stochastic volatilities are assumed to be orthogonal to one another. Therefore, no a priori reason exists to suppose that shifts in the volatility of China and ASEAN cycles to be correlated with one another.

The estimates show that China's economic activity has exhibited short volatility cycles, particularly when compared to global economic activity. Shocks in China's economic activity spiked during the GFC and in 2012; both periods were characterized by elevated concerns over economic growth. The estimates imply that a downturn in China's economic activity is associated with greater economic volatility. Since 2008 ASEAN real cycle volatility has moved in phase with China's.

During the commodity price boom of the 2000s ASEAN inflation volatility rose sharply, but progressively declined following the GFC. This is consistent with the relatively benign global inflationary environment post-GFC. From 2014 inflation volatlity began to rise, as commodity prices collapsed.

From 2011 to 2014, as the region grew rapidly and witnessed significant capital inflows, credit and financial volatility all declined as financial risk premia across the region fell. Spikes in the size of financial volatility have been interpreted as uncertainty shocks. Since mid-2014 the size of China and global economic economic activity shocks spiked. With a lag, ASEAN real and financial volatility also rose, and is consistent with greater global financial uncertainty over the last year. 
Figure 3: Size of China and ASEAN Macroeconomic Shocks, 2005-15

( $y$-axis is expressed in terms of standard deviation)
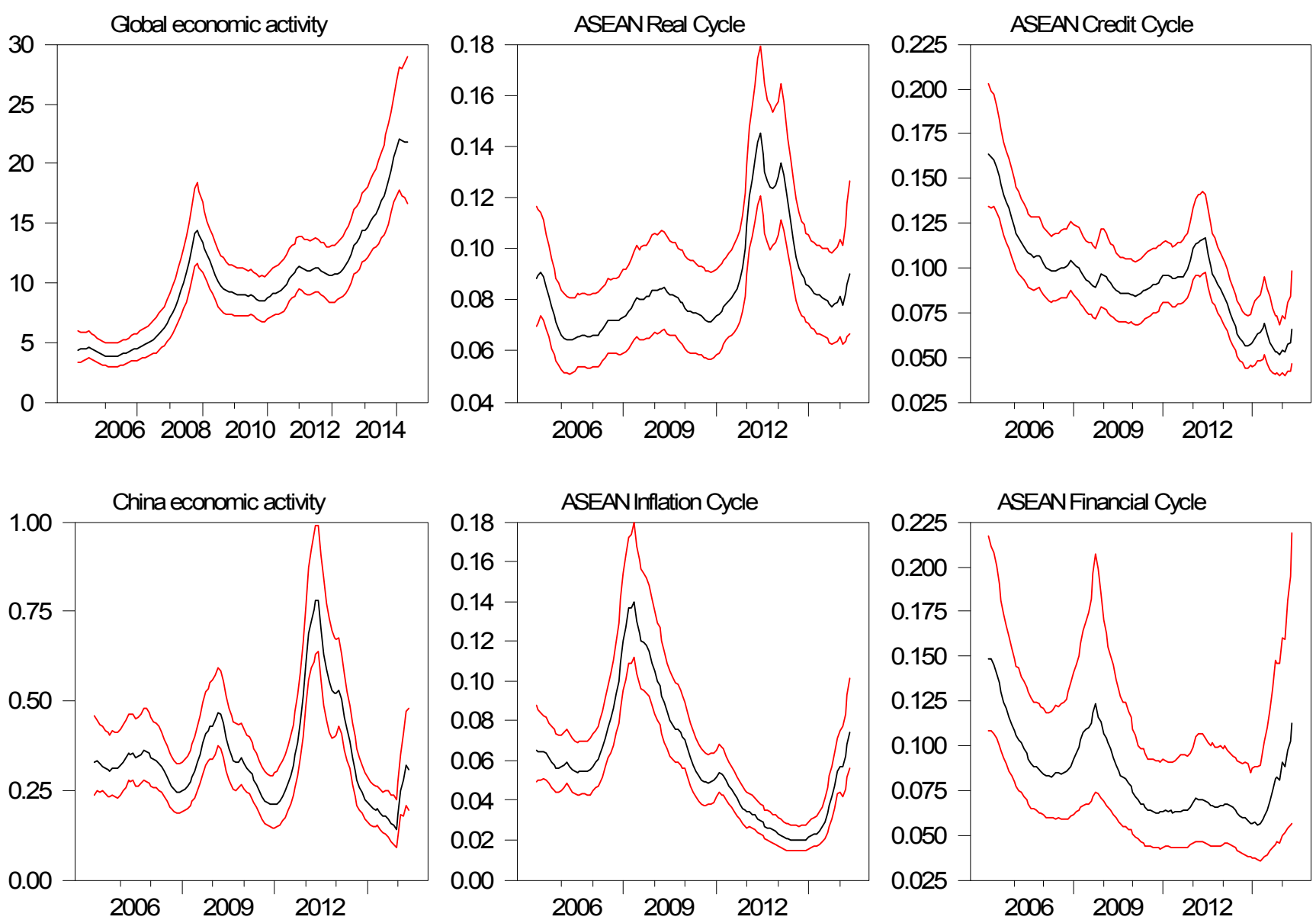

Source: Author's calculations. 


\section{B. Explanatory Power of China Growth Shocks on the ASEAN Economic Cycle}

This section assesses the relative explanatory power of shocks in China's economic growth for ASEAN real dynamics using time-varying variance decomposition, which determines how much of the forecast error variance of the ASEAN economic cycle can be explained by exogenous China growth shocks at different horizons. Figure 4 allows for an assessment of the importance of China and world economic growth shocks on ASEAN economic activity during specific economic episodes.

First, the growing explanatory power of China and global growth shocks for ASEAN economic activity over the last 15 years is consistent with ASEAN's growing financial and trade links with the region and world. The second result to notice is that China growth shocks have greater explanatory power than global growth shocks over short rather than longer-term horizons. Global shocks appear more important over the longerterm. This implies regional shocks diffuse more rapidly than global ones into

Figure 4: Time-Varying Variance Decomposition for ASEAN Economic Activity

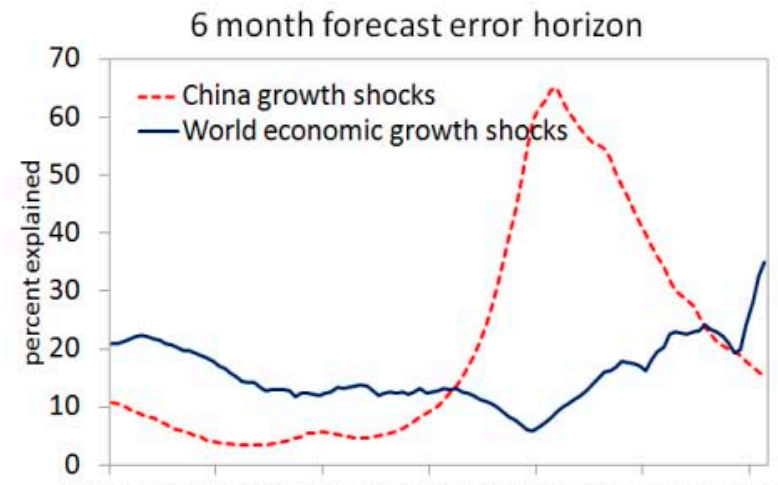

2006:032007:09 2009:032010:09 2012:032013:09 2015:03

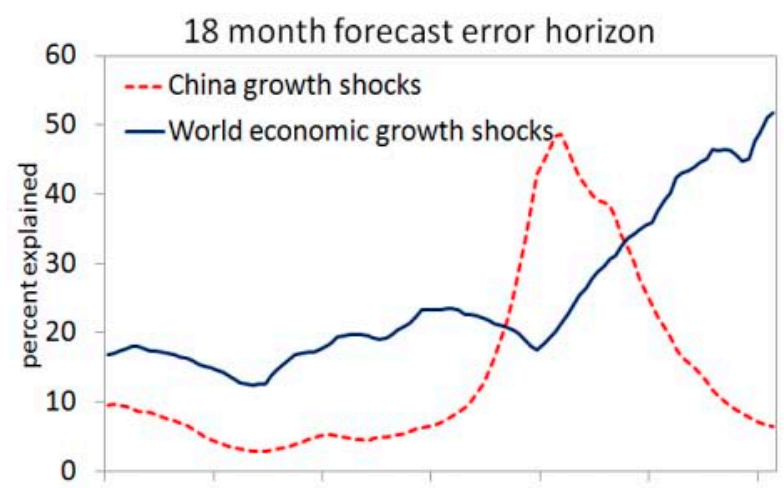

2006:03 2007:09 2009:03 2010:09 2012:03 2013:09 2015:03

Source: Author's calculations.

ASEAN economic activity. Third, based on the short-term (six month) forecast error horizon the time-varying estimates show that the explanatory power of China growth shocks for the ASEAN real economic cycle rose significantly in the years following the GFC. The six month forecast power of China growth innovations for ASEAN real economic activity peaked in 2012:6 at around 60 percent. The sharp rise between 2011:1 and 2013:1 in the explanatory power of China growth shocks for ASEAN real economic activity coincided with a period during which concerns in China over slowing economic activity were heightened. From 2014 the relative importance of China shocks has declined, while global growth innovations became more important. This is perhaps unsurprising, given that Figure 3 shows that the size of global growth shocks began to rise. This finding highlights the importance of allowing for the size of growth shocks to change across time to more accurately capture the relationship between external and domestic growth fluctuations. Finally, although not reported, similar patterns are observed for the ASEAN inflation cycle. 


\section{InNovation Accounting of A China SLOWdown on ASEAN}

This section examines the impact of China growth shocks on ASEAN macroeconomic developments.

\section{A. What is the Impact of China's Growth on ASEAN Economic Activity?}

Figure 5 presents a set of elasticity values for a temporary 1 percent decline in China's economic growth. The elasticity values are calculated from the time-varying response functions. ${ }^{6}$ Responses drawn at each date in time across the sample show that the 200809 GFC marked a progressive turning point after which growth spillovers from China to ASEAN (particularly to EMEs in the region) began growing (Appendix B).

All else equal, in response to a 1 percent slowdown in China economic activity the model estimates that:

- Malaysia's economic activity declines by around 0.28 percent and the Philippines by 0.26 percent. The average impact of a 1 percent China slowdown on ASEAN EMEs is around a quarter percent, which is more than double the size of the impact based on coefficient values in July 2006, at which point the average estimated growth effect was around 0.10 .
Figure 5: Elasticity Value to a Change in China Economic Growth

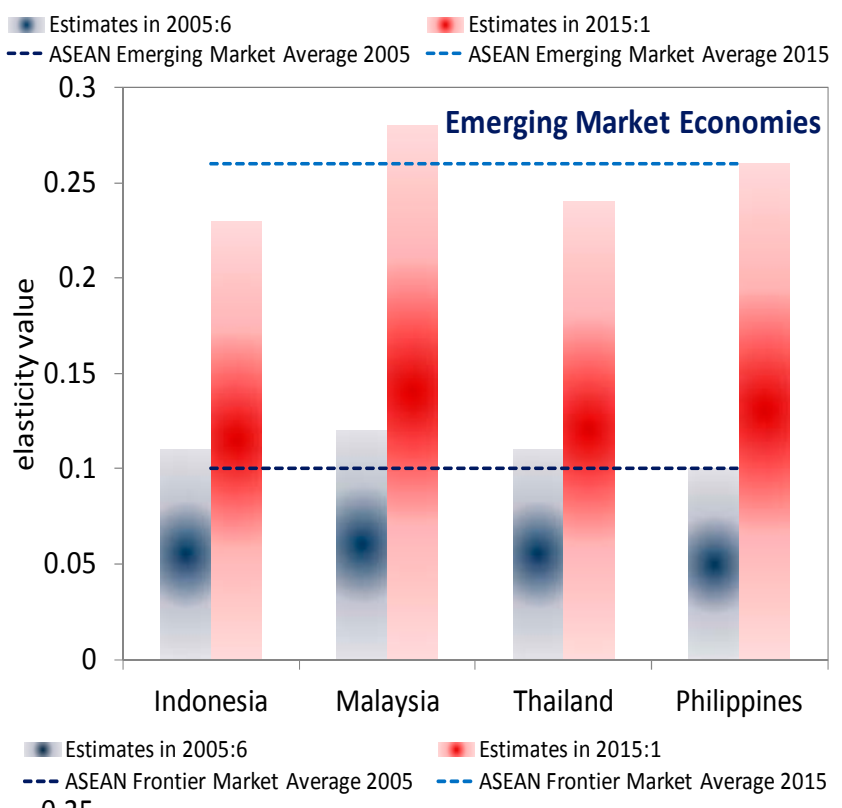

--- ASEAN Frontier Market Average 2005 --- ASEAN Frontier Market Average 2015

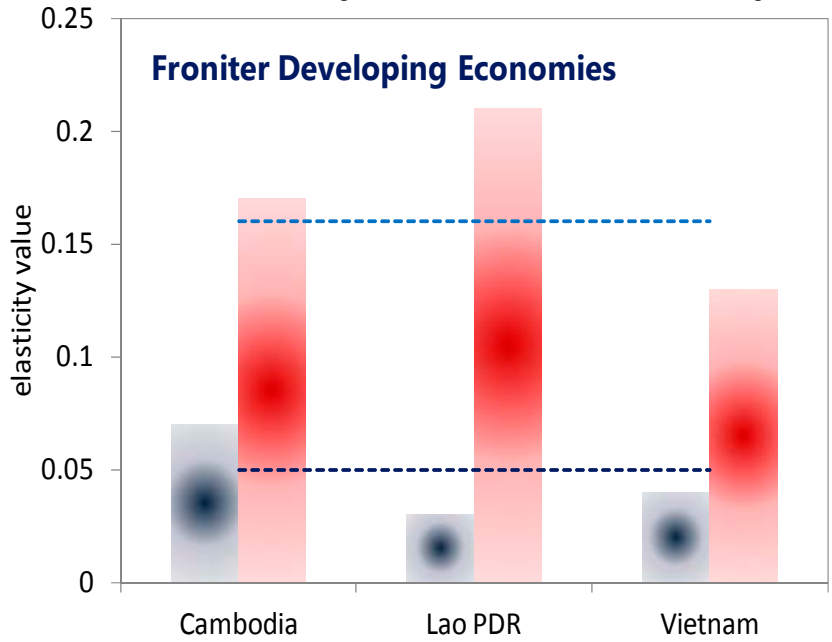

Source: Author's calculations.

\footnotetext{
${ }^{6}$ Interpretation of elasticities based of simple coefficient values in cointegrated vector autoregressive model may turn out to be incorrect, as they disregard the full dynamics of the system (see Johansen, 2005, for a discussion).
} 
- Although having doubled in size since 2006, the average impact of a China growth slowdown on economic activity in ASEAN FDE countries in 2015 is smaller than for EMEs, with an average elasticity value of around 0.16 . Vietnam's economic activity declines by around 0.13 percent. Cambodia and Lao P.D.R. (the country with the highest share of

Figure 6: Response of ASEAN Inflation Cycle to a China Growth Slowdown exports to China) are more adversely affected with growth slowing by 0.17 percent and 0.21 percent, respectively. The lower elasticity values for FDEs compared with EMEs are consistent with their relatively weaker trade and financial integration in the region. ${ }^{7}$

The impact of a China economic slowdown on growth in ASEAN has more than doubled in magnitude since the GFC, implying that

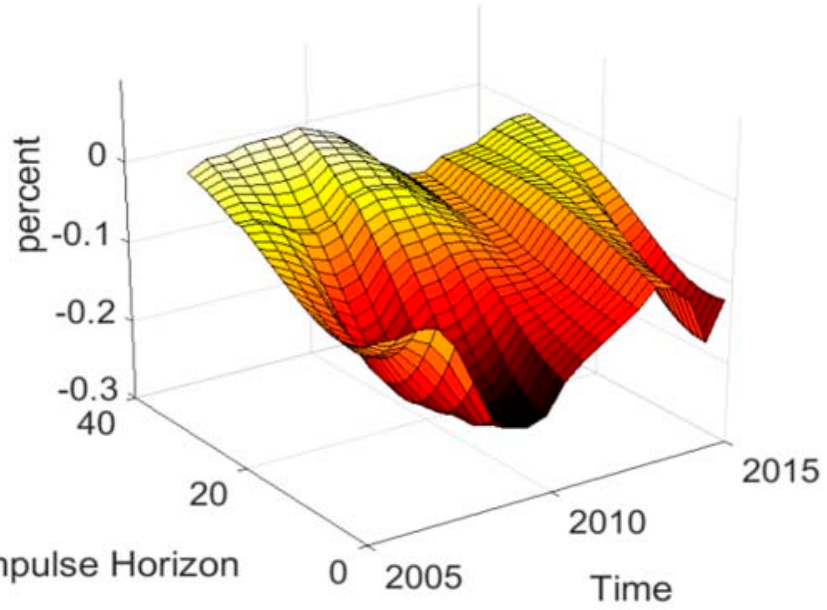

Source: Author's calculations. the synchronicity in economic cycles between China and ASEAN has risen, although the impact varies from country-to-country. In the short-run a China slowdown also pushes deflationary pressures on the region, with inflation declining across ASEAN (Figure 6). ${ }^{8}$ The positive comovement between output and inflation implies that shocks emanating from China to ASEAN have been primarily demand rather than supply driven.

\section{B. Does a Slowdown in China Influence Financial Conditions in ASEAN?}

Financial spillovers can emanate from real or financial sources to other countries through financial markets. These spillovers can reflect both realized and expected events. There are a number of channels through which a slowdown in China could influence financial conditions in ASEAN: (i) rising financial development, cross-border holdings of financial assets and overseas investment by private sector entities in China have grown; (ii) intra-regional financial flows may be further promoted by the internationalization of the renminbi.

\footnotetext{
${ }^{7}$ Canonical real business cycle models predict that the response of output to international shocks is smaller in those economies with low international risk sharing.

${ }^{8}$ The 3D-graphs of the time-varying relationship graphs are to be read in the following way: along the $x$-axis the starting months are aligned from 2005:1 to 2015:6; on the $y$-axis the months after the China growth shock are displayed; and on the $z$-axis the value of the ASEAN inflation response to a China growth slowdown.
} 
Figure 7 shows that the ASEAN financial cycle factor is consistent with both the GFC period, and subsequent China-related events. ${ }^{9}$ The index declines but remains relatively stable until 2007, when a sharp and sustained fall is recorded. Once identified it is natural to study fluctuations in global asset markets and to see whether they follow the ASEAN financial cycle. The data show a rise in the VIX and corporate bond spread (Baa - Aaa), both commonly used as measures of degree of market stress, have been typically associated with the weakening in the ASEAN financial cycle.

\section{Figure 7: ASEAN Financial Cycle and Global Risk}
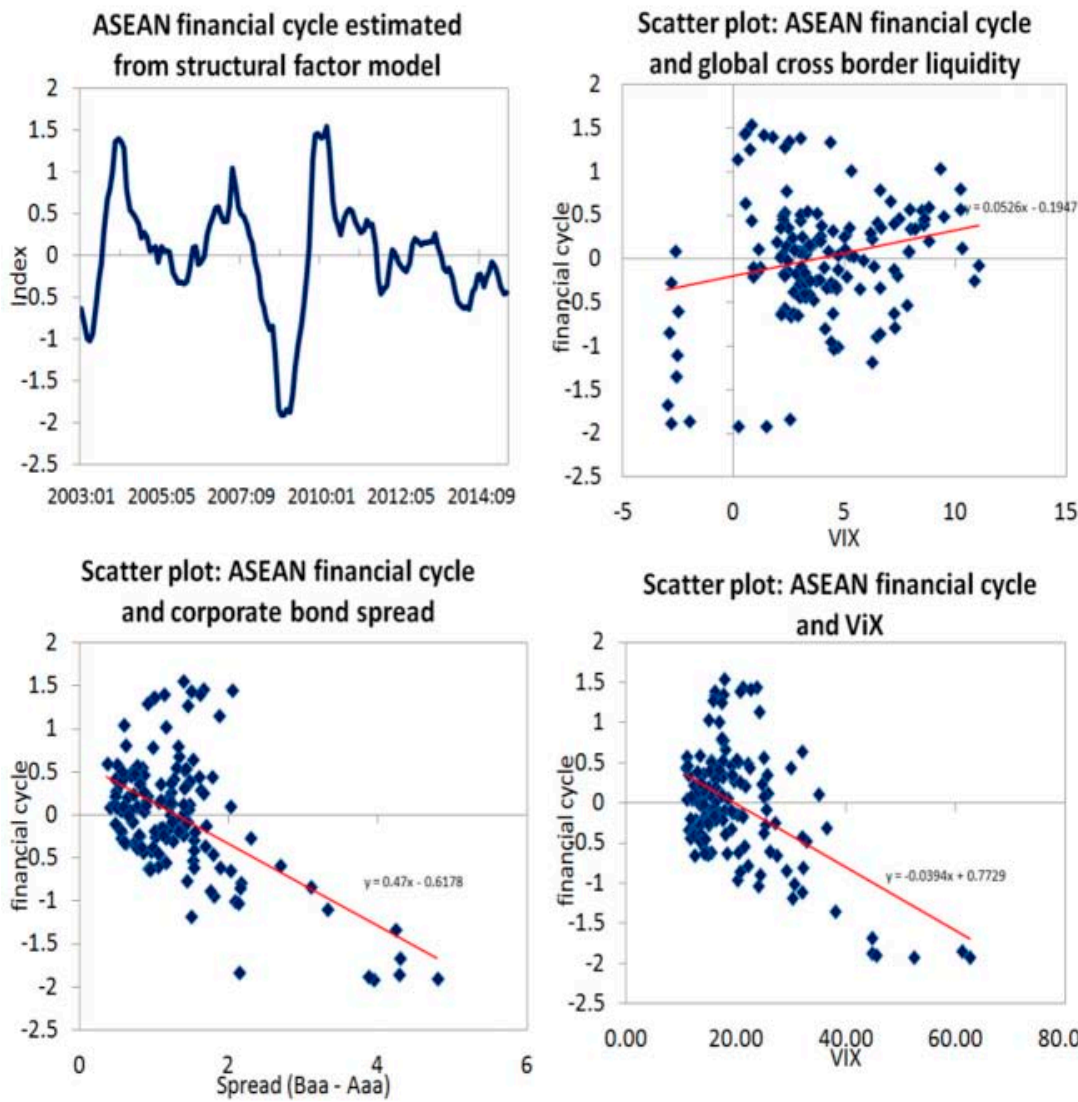

Scatter plot: ASEAN financial cycle and ViX

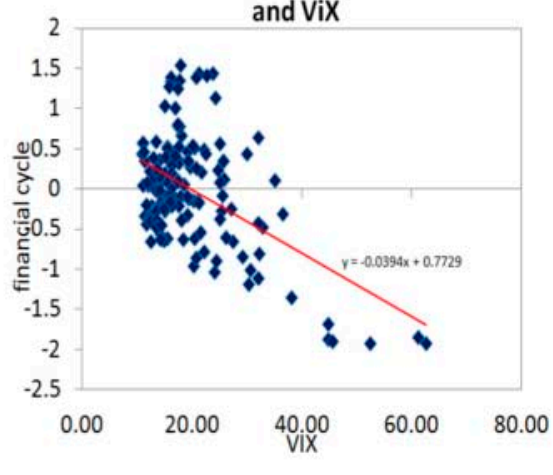

Source: Author's calculations, BIS, Haver Analytics, CEIC

The correlation between global risk aversion and the ASEAN financial cycle has been understood as reflecting the joint evolution of the effective risk appetite of the market as well as realized market volatility. As noted in Rey (2015), both aggregate volatility of asset markets and the time-varying degree of risk aversion of markets can be interpreted as reflecting investment preferences.

The response of ASEAN financial markets to an economic slowdown in China is reported in Figure 8. These estimates account for the spillover effects from China to ASEAN economies and vary depending on the state of financial risk aversion and the stage of the business cycle. The time-varying estimates show that financial conditions in the region tighten to a China growth slowdown, as reflected by declining equity prices and a rise in long-term interest rates. This effect has progressively strengthened over the last 15 years. In response to a

\footnotetext{
9 The estimated ASEAN financial factor is rotated such that it positively comoves with prices; i.e., an increase in the index is interpreted as an increase in asset prices. The common financial cycle factor is obtained via cumulation. This implies, in practical terms, that positive and negative values displayed in the chart cannot be interpreted as such and that they do not convey any specific information per se. Rather, it is the overall shape and the turning points that are of interest and deserve particular attention.
} 
1 percent slowdown in China economic activity, based on coefficient values drawn in 2015, equity prices across ASEAN EMEs decline cumulatively by around 2.5 percent.

Consistent with tighter financial conditions, Figure 8 also shows that long-term rates rise in response to a slowdown in China economic activity. The effect on bond yields has risen since the 2008 GFC. More specifically, among EMEs (Indonesia, Malaysia, Philippines, and Thailand) long-term interest rates rise by, on average, 2-8 basis points. With developed capital markets, for these ASEAN countries, the findings are in line with the existence of both a portfolio balance channel and a signaling channel, in which market participants absorb news on China economic activity as a signal for domestic growth prospects. The findings are in line with IMF (2014) and Rafiq (2015b), which showed that, for emerging market countries in Asia, financial spillovers from systematically important countries are transmitted through their impact on bond and equity prices..$^{10}$

Due to limited capital and equity market development, the first-round spillover effects of a China slowdown on ASEAN FDE countries via the financial channel are likely to be less important. However, there may be second-round effects on FDEs resulting from the direct impact of a China slowdown on ASEAN EME financial markets. Much of the banking sector in Cambodia and Lao P.D.R. is composed of foreign banks, particularly from Malaysia and Thailand. In support of this hypothesis, the results show that a slowdown in China growth tightens credit conditions across FDE (and EME) ASEAN countries, with credit growth falling (Figure 9). This effect has strengthened since the GFC. These findings imply secondround financial effects from ASEAN EMEs to FDEs, and the emergence of a common financial cycle across ASEAN that explains covariability in credit and asset price cycles. In essence, the decline in credit growth, coupled with rising interest rates and the relationship between the ASEAN financial cycle and global risk aversion illustrated in Figure 7 is in line with Brunnermeier and De Gregorio and others (2012) and Borio and Disyatat (2011), which noted there to be a positive global feedback loop between credit supply, asset price inflation and a compression of spreads. ${ }^{11}$ Taken together, stronger economic growth in China, through a compression in risk premia, could contribute to the pro-cyclicality of credit flows into ASEAN.

\footnotetext{
${ }^{10}$ The impact of China on regional markets could be even larger than estimated on the basis of direct spillovers. In particular, if other systemic markets outside of Asia were impacted by China, for example due to confidence effects that lead to a global risk-off episode with a rise in the VIX, spillovers from China to ASEAN could be more than twice as large.

${ }^{11}$ Smaller risk premiums amplify the credit boom. Measured risk is low and balance sheets look healthier as asset prices go up. By relaxing value-at-risk constraints, this creates additional space for lending and for credit, and so on an important positive feedback loop between credit creation and risk spreads. It contributes to the procyclicality of credit flows and their importance in the build-up of financial fragility.
} 
Figure 8: Response of Equity and Long-Term Rates in ASEAN to a China Growth Slowdown
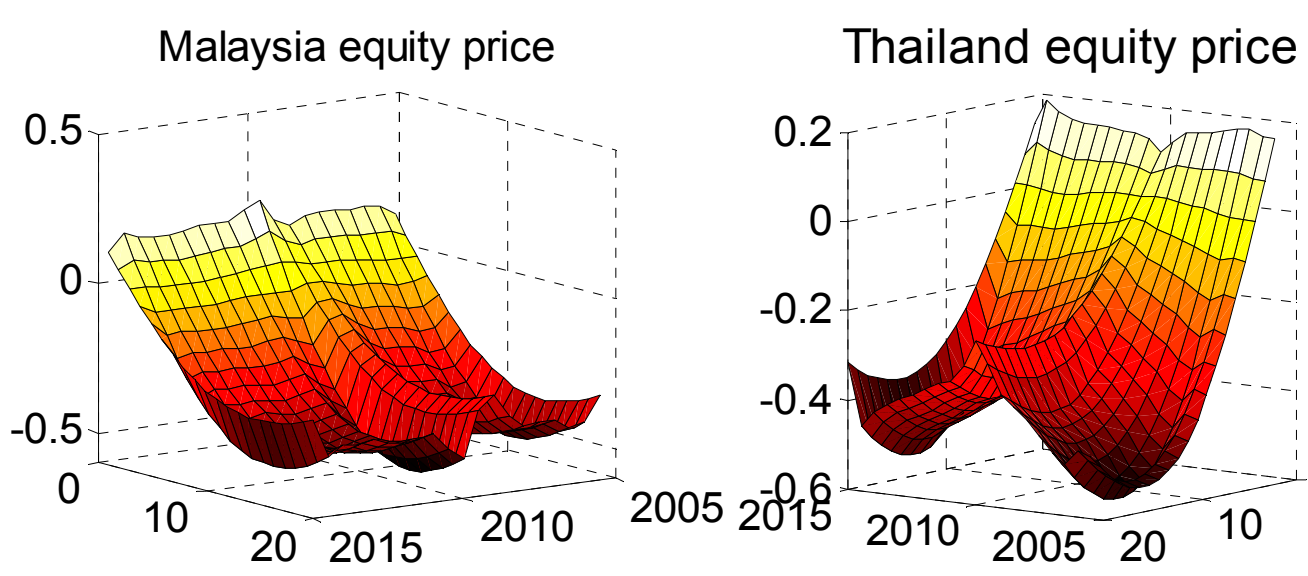

Indonesia equity price

Philippines equity price

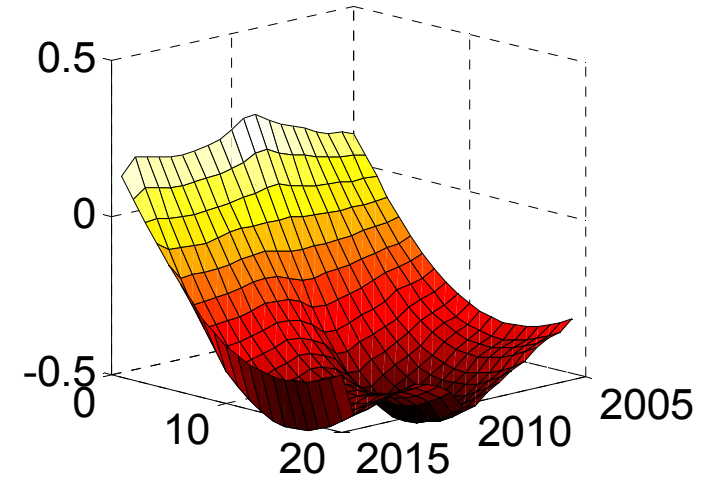

Indonesia bond yield

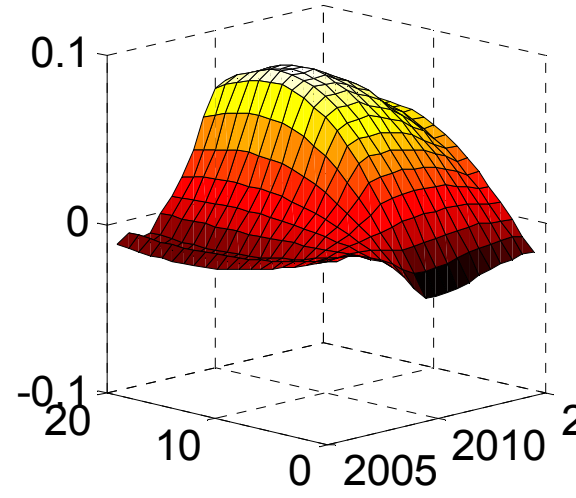

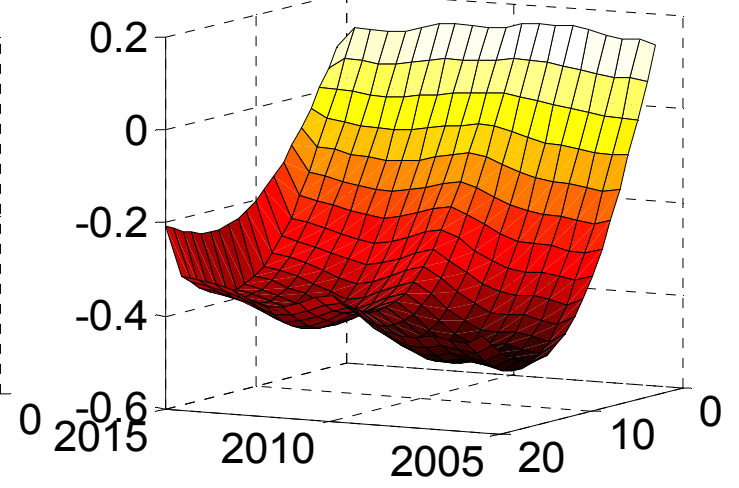

Philippines bond yield

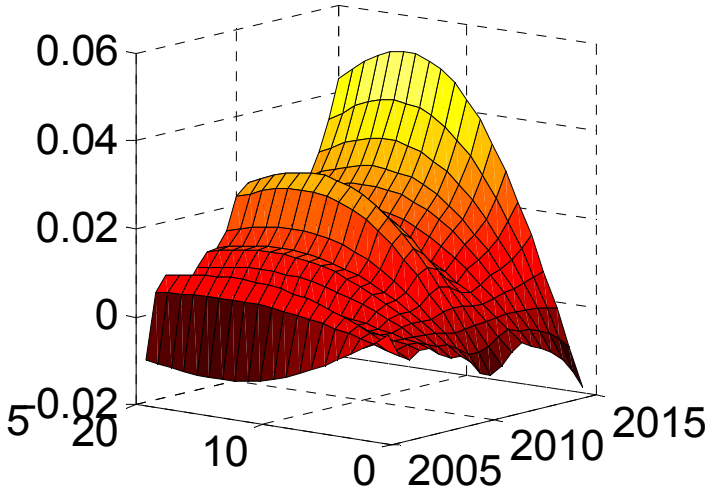

Source: Author's calculations. 
Figure 9: Responses of Credit Cycle in ASEAN to a China Slowdown
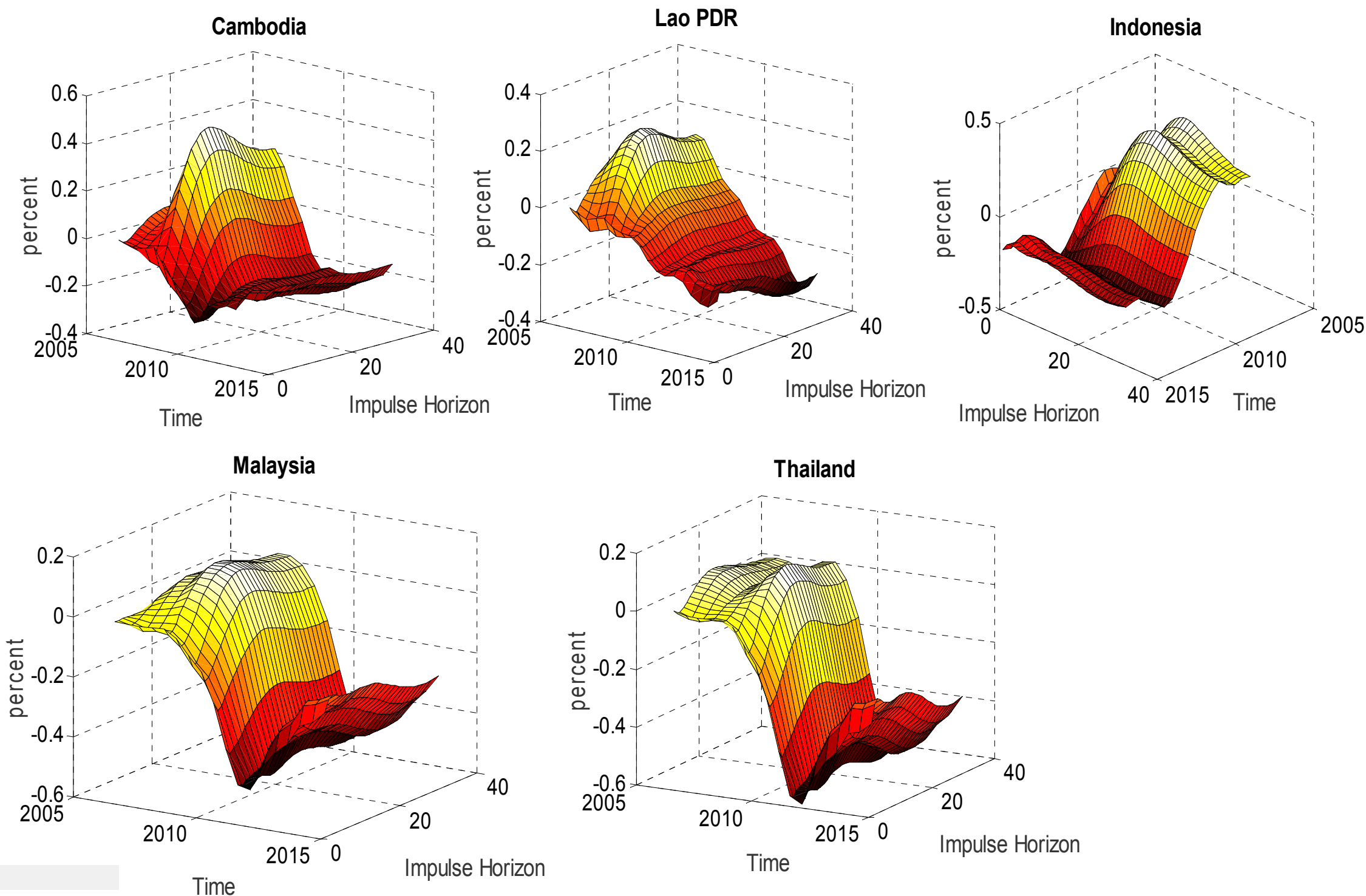

Source: Author's calculations. 
The results are consistent with the idea that regional economic and financial factors have begun exerting a greater influence on financial conditions in individual ASEAN countries. This has two potential implications: (i) financial cycles that are driven by China could result in inappropriate monetary and financial conditions in ASEAN via financial spillovers; or (ii) the China influence, as an important regional force, may counterbalance the impact of changes in financial conditions emanating from advanced economies from outside the region.

\section{Summary ANd Policy Implications}

The international aspect of the transmission mechanism has become an essential ingredient in policy discussions. The results in this paper are consistent with the view that demand management in systemically important countries like China has important consequences for the ASEAN region. ${ }^{12}$ China shocks act as a common disturbance across ASEAN, and the impact of China's economic activity on ASEAN growth has increased over the last 15 years. An economic slowdown in China also impacts asset prices across ASEAN while the credit cycle slows. This is evidence of an ASEAN financial cycle, and implies that ASEAN countries may unintentionally import macro conditions from China via financial spillovers. ${ }^{13}$ Moreover, the experience of ASEAN EMEs implies that as ASEAN FDEs' trade and financial linkages with the region grow they are increasingly likely to be buffeted by shocks from China.

These findings suggest a number of policy implications. First, ASEAN countries should preemptively upgrade macroeconomic policies and strengthen macroprudential frameworks. Second, increasingly allowing greater exchange rate flexibility would be important to buffer against external shocks. As China reforms its exchange rate regime this question will be of increasing policy interest for ASEAN. Third, there is a need to enhance surveillance of crossborder financial flows to derive a comprehensive picture of the deeper network of interconnections and spillovers from China to ASEAN while identifying data gaps and working toward their closure.

\footnotetext{
${ }^{12}$ Rey (2015).

${ }^{13}$ See Rey (2015) for a discussion on domestic importation of global financial conditions.
} 
Appendix A: Data definitions and Panel Blocks

\begin{tabular}{|c|c|c|c|c|c|c|c|}
\hline & \multicolumn{4}{|c|}{ Emerging Market ASEAN } & \multicolumn{3}{|c|}{ Frontier Market ASEAN } \\
\hline & Indonesia & Malaysia & Thailand & Philippines & Cambodia & Lao PDR & Vietnam \\
\hline $\begin{array}{l}\text { Real economic } \\
\text { activity block } \\
\left(X_{t}^{y}\right)^{\ddagger}\end{array}$ & $\begin{array}{l}\text { Industrial } \\
\text { production }\end{array}$ & $\begin{array}{l}\text { Industrial } \\
\text { production }\end{array}$ & $\begin{array}{l}\text { Industrial } \\
\text { production }\end{array}$ & $\begin{array}{l}\text { Industrial } \\
\text { production }\end{array}$ & $\begin{array}{l}\text { Industrial } \\
\text { production }\end{array}$ & $\begin{array}{l}\text { Industrial } \\
\text { production }\end{array}$ & $\begin{array}{l}\text { Industrial } \\
\text { production }\end{array}$ \\
\hline $\begin{array}{l}\text { Inflation block } \\
\left(X_{t}^{\pi}\right)\end{array}$ & $\begin{array}{l}\text { Consumer } \\
\text { price } \\
\text { index }\end{array}$ & $\begin{array}{l}\text { Consumer } \\
\text { price } \\
\text { index }\end{array}$ & $\begin{array}{l}\text { Consumer } \\
\text { price } \\
\text { index }\end{array}$ & $\begin{array}{l}\text { Consumer } \\
\text { price index }\end{array}$ & $\begin{array}{c}\text { Consumer } \\
\text { price } \\
\text { index }\end{array}$ & $\begin{array}{l}\text { Consumer } \\
\text { price index }\end{array}$ & $\begin{array}{l}\text { Consumer } \\
\text { price index }\end{array}$ \\
\hline Credit block $\left(X_{t}^{c}\right)$ & $\begin{array}{l}\text { Private } \\
\text { sector } \\
\text { credit } \\
\text { growth }\end{array}$ & $\begin{array}{l}\text { Private } \\
\text { sector } \\
\text { credit } \\
\text { growth }\end{array}$ & $\begin{array}{l}\text { Private } \\
\text { sector } \\
\text { credit } \\
\text { growth }\end{array}$ & $\begin{array}{l}\text { Private } \\
\text { sector credit } \\
\text { growth }\end{array}$ & $\begin{array}{l}\text { Private } \\
\text { sector } \\
\text { credit } \\
\text { growth }\end{array}$ & $\begin{array}{l}\text { Private } \\
\text { sector credit } \\
\text { growth }\end{array}$ & $\begin{array}{l}\text { Private sector } \\
\text { credit growth }\end{array}$ \\
\hline $\begin{array}{l}\text { Financial block } \\
\left(X_{t}^{f}\right)\end{array}$ & $\begin{array}{l}\text { Jakarta } \\
\text { stock } \\
\text { index and } \\
10 \text {-year } \\
\text { bond yield }\end{array}$ & $\begin{array}{l}\text { Kuala } \\
\text { Lumpur } \\
\text { stock } \\
\text { index and } \\
10 \text {-year } \\
\text { bond yield }\end{array}$ & $\begin{array}{l}\text { Thailand } \\
\text { stock } \\
\text { index \& } \\
10 \text {-year } \\
\text { bond yield }\end{array}$ & $\begin{array}{l}\text { Philippines } \\
\text { stock index } \\
\text { and } 10 \text {-year } \\
\text { bond yield }\end{array}$ & - & - & - \\
\hline
\end{tabular}

Global economic activity $\left(y_{t}^{g}\right)$

China economic activity $\left(y_{t}^{c}\right)$

Based on an updated monthly index from Kilian (2009).

Coincident indicator: quarterly real GDP (Haver Analytics); Residential Investment (CEIC); Retail sales (CEIC); Industrial production (CEIC).

Notes: All data were retrieved from publicly available sources.

₹ Industrial production can be viewed as a more homogenous measure of the data generating process for economic activity, since some of the segments of

GDP that are important for ASEAN countries (such as agriculture and allied products) are driven by factors that are relatively exogenous to shocks. 
Appendix B: Response of ASEAN Economic Activity to a Slowdown in China Economic Activity
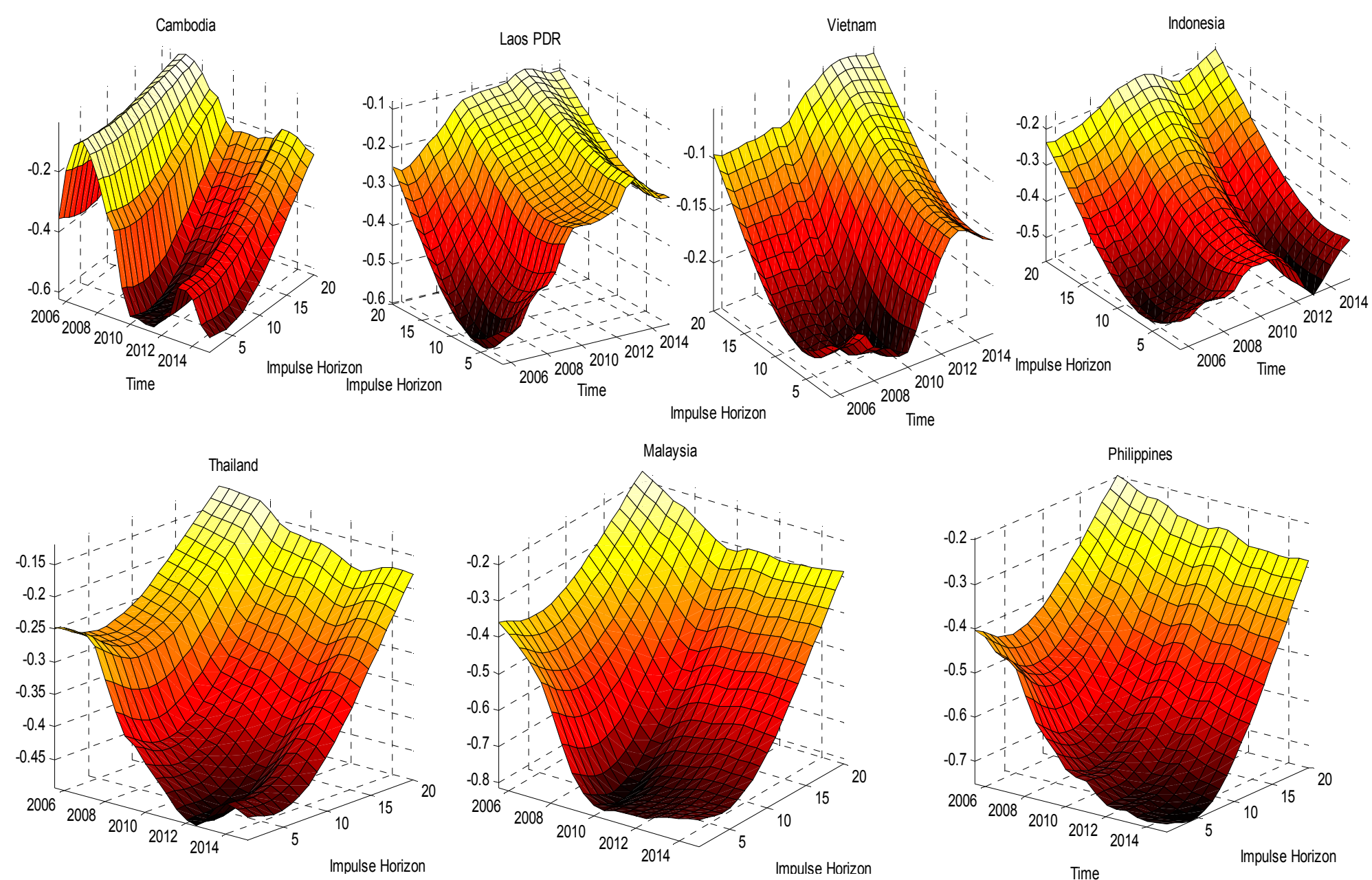

Source: Author's calculations.

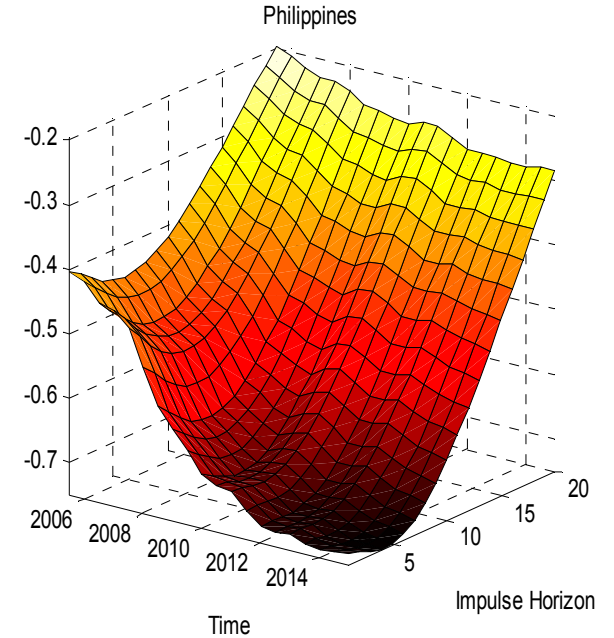




\section{REFERENCES}

Boivin, J. and M. P. Gianonni, 2010, 'International Dimensions of Monetary Policy', in International Dimensions of Monetary Policy, ed. J. Gali and M. Gertler, 429-478. National Bureau of Economic Research, University of Chicago Press.

Borio, C. and Piti Disyatat, 2011, 'Global Imbalances and the Financial Crisis: Link or no Link?,' Bank for International Settlements, BIS Working Papers No. 346.

Brunnermeier, M., J. De Gregorio, and others, 2012, 'Banks and Cross-Border Capital Flows: Policy Challenges and Regulatory Responses,' Committee on International Economic Policy and Reform.

Clark, T. E., and K. Shin, 2000, 'The sources of fluctuations within and across countries', in Intranational macroeconomics, ed. Gregory Hess and Eric van Wincoop, 189-220. Boston, MA: Cambridge University Press.

Del Negro, M. and C. Otrok, 2008, 'Dynamic factor models with time-varying parameters: measuring changes in international business cycles,' Federal Reserve Bank of New York, Staff Reports No. 326.

Helbling, T., R. Huidrom, M. A. Kose and C. Otrok, 2010, 'Do Credit Shocks Matter? A Global Perspective', IMF Working Paper No. WP/10/261.

International Monetary Fund, 2014, Asia and Pacific Regional Economic Outlook (April).

Johansen. S., 2005, 'Interpretation of Cointegrating Coefficients in the Cointegrated Vector Autoregressive Model', Oxford Bulletin of Economics and Statistics, 67(1): 93-104.

Kilian, L., 2009, Not all oil price shocks are alike: Disentangling demand and supply shocks in the crude oil market, American Economic Review, 99(3), 1053-69.

Lumsdaine, R. L., and E. S. Prasad, 2003, 'Identifying the common component in international economic fluctuations,' Economic Journal, 113(484): 101-27.

Primiceri, G. E., 2005, 'Time varying structural vector autoregressions and monetary policy,' Review of Economic Studies, 72(3): 821-52.

Ravazzolo, F. and J. L. Vespignani, 2015, 'A New Monthly Indicator of Global Real Economic Activity,' Federal Reserve Bank of Dallas, Working Paper No. 244.

Rafiq, S., 2013, 'The Growth and Stabilization Properties of Fiscal Policy in Malaysia,' IMF Working Paper No. 13/149.

Rafiq, S., 2014, 'Decomposing U.K. Inflation Expectations Using Survey Based Measures,' Macroeconomic Dynamics, 18(7): 1508-1538. 
Rafiq, S., 2015a, 'What Do Energy Prices Tell Us About UK Inflation?,' Economica, 81: 293-310.

Rafiq, S. 2015b, 'The Effects of U.S. Unconventional Monetary Policy on Asia Frontier Developing Economies,' International Monetary Fund, Working Paper No. WP/15/18.

Rey, H., 2015, 'Dilemma not Trilemma: The global financial cycle and monetary policy Independence,' NBER Working Paper No. 21162.

Stock and Watson, 1989, 'New Indexes of Coincident and Leading Economic Indicators' in NBER Macroeconomics Annual, Volume 4, pp. 351-409. 